Collection: 3rd International Elm Conference, Florence (Italy - 2013)

"The elms after 100 years of Dutch Elm disease"

Guest Editors: A. Santini, L. Ghelardini, E. Collin, A. Solla, J. Brunet, M. Faccoli, A. Scala, S. De Vries, J. Buiteveld

\section{Genetic variation and heritability estimates of Ulmus minor and Ulmus pumila hybrids for budburst, growth and tolerance to Ophiostoma novo-ulmi}

\author{
Alejandro Solla ${ }^{(1)}$, Juan Carlos López-Almansa ${ }^{(2)}$, Juan A Martín ${ }^{(3)}$, Luis \\ Gil $^{(3)}$
}

Seedlings obtained by crossing Ulmus minor and $U$. minor $\times U$. pumila clones were assessed for flowering, bark beetle damage, vegetative budburst, height growth and resistance to Ophiostoma novo-ulmi. Ramets and open pollinated seedlings obtained from the parent trees were assessed for the same traits. Most progenies had similar traits to their parents, but some presented heterosis in annual growth or resistance to 0 . novo-ulmi. Leaf wilting was significantly lower in progenies with $U$. minor $\times U$. pumila rather than $U$. minor as female parent $(21.5$ and $30.6 \%$, respectively; $P<0.05)$. Resistance to $O$. novoulmi increased significantly as a function of increased amounts of $U$. pumila germplasm from the female parent, suggesting that resistance to Dutch elm disease is primarily transmitted from the mother. Budburst occurred earlier in seedlings with low rather than high growth rates $(P=0.0007)$ and percentage of wilting was negatively related to early budburst $(P<0.0001)$. Other phenotypic relations included percentage of flowering trees and annual height growth $\left(r_{\mathrm{p}}=0.44 ; P=0.0042\right)$, percentage of flowering trees and vegetative budburst $\left(r_{\mathrm{p}}=-0.53 ; P=0.0004\right)$ and percentage of beetle-affected trees and annual height growth $\left(r_{\mathrm{p}}=0.60 ; P<0.0001\right)$. Heritability estimates obtained from the regression and variance components methods ranged from $0.06 \pm 0.04$ to 0.64 $\pm 0.18,0.10 \pm 0.05$ to $0.69 \pm 0.17$, and $0.13 \pm 0.32$ to $0.71 \pm 0.22$ for bud burst, growth and tolerance to 0 . novo-ulmi, respectively. Broad- and narrowsense heritability values were higher when estimated 60 days post inoculation (dpi) than 15, 30 or 120 dpi. Heritability estimates and genetic gains reported indicate a high degree of additive genetic control and show the effectiveness of selection for Dutch elm disease resistance and rapid tree growth.

Keywords: Quantitative Genetics, Tree Breeding, Invasive Pathogen, Inheritance, Additive Genetic Variance, Non-additive Genetic Variance, Heterosis, Genetic Gain

\section{Introduction}

The field elm (Ulmus minor) was formerly a major component of riparian forests and municipal planting in southern Europe. Valuable ornamental traits, adaptability to urban environments and simplicity of establishment and management are the notable features of this species. However, U. minor has virtually disappeared from urban landscaping due to the spread of the lethal Dutch elm disease (DED), which is caused by the pathogen Ophiostoma novo-ulmi (Brasier 2000, Solla et al. 2008). The fungus is transmitted from diseased to healthy elms by elm bark beetles, in particular Scolytus scolytus and $S$. multistriatus, the two main vectors in
U. pumila (Mittempergher \& Santini 2004, Martín et al. 2014). Ulmus pumila is not a European native and was probably introduced into Spain in the $16^{\text {th }}$ century as an ornamental and into Italy in the 1930 s to replace dying elms. Natural hybridization with $U$. minor trees in these countries has produced genetic introgression, leading to a complex taxonomy (Cogolludo-Agustín et al. 2000).

Screening has been used to identify European elms with low disease susceptibility (Pinon et al. 2005, Santini et al. 2005, Solla et al. 2005a). These studies have identified $U$. pumila individuals and $U$. minor $\times U$. pumila hybrids with low susceptibility and rapid height growth. As ornamentals, however, $U$. pumila and $U$. minor $\times U$. pumila have several features that compare unfavorably with $U$. minor, the species they are intended to replace. Excessively fine branching, excurrent habit, small leaves, branch brittleness and twig mortality are normally undesirable features in urban environmental planting (Heybroek 1957, Lester \& Smalley 1972b). The Spanish elm breeding programme has therefore begun a series of backcrosses using $U$. minor as the source of improved ornamental traits and $U$. minor $\times U$. pumila as the source of disease resistance and rapid height growth. Fast growth is definitely a desirable trait for the common landscape use of trees in southern Europe. Delayed vegetative budburst is similarly desirable in areas with spring frosts or where early defoliating insects such as Euproctis chrysorrhoea cause considerable leaf damage. Flower and seed production are important characters to study in an $F_{1}$ population, especially if successive breeding cycles are to be

(1) Ingeniería Forestal y del Medio Natural, Universidad de Extremadura, Avenida Virgen del Puerto 2, E-10600 Plasencia (Spain); (2) Departamento de Desarrollo Sostenible, Universidad Católica de Ávila, Canteros s/n, E-05005 Ávila (Spain); (3) ETSI Montes, Forestal y del Medio Natural, Universidad Politécnica de Madrid, Ciudad Universitaria s/n, E-28040 Madrid (Spain) trol insect vectors are now largely unacceptable. Systemic chemicals have proven too toxic for general use (Martín et al. 2008, $2010,2012)$ and biological control treatments appear to be ineffective (Solla \& Gil 2003, Vivas et al. 2012a). As a result, replanting efforts now focus on other tree genera.

From a genetic point of view, re-introducing elms into municipal landscaping appears to be both desirable and feasible. A genetic basis for disease resistance to DED has been established in Europe using native elm species and clones, especially in hybrid combinations between and within $U$. minor and

\section{@ Alejandro Solla (asolla@unex.es)}

Received: Dec 31, 2013 - Accepted: Sep 23, 2014

Citation: Solla A, López-Almansa JC, Martín JA, Gil L, 2014. Genetic variation and heritability estimates of Ulmus minor and Ulmus pumila hybrids for budburst, growth and tolerance to Ophiostoma novo-ulmi. iForest 8: 422-430 [online 2014-12-14] URL: http://www.sisef.it/iforest/contents/? id=ifor1227-007

Communicated by: Alberto Santini 


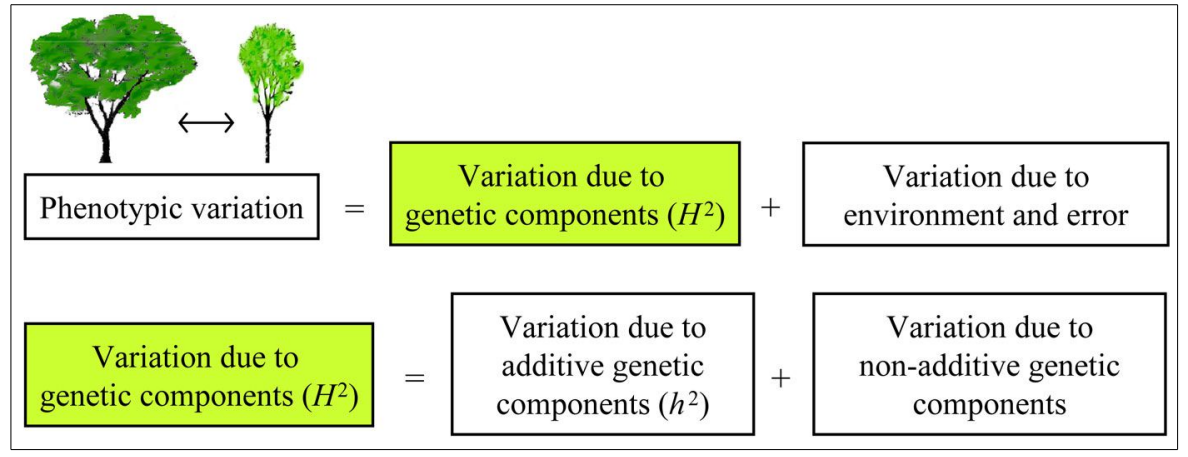

Fig. 1 - Components of phenotypic variation, including broad-sense heritability $\left(H^{2}\right)$ and narrow-sense heritability $\left(h^{2}\right)$.

performed. Information on the incidence of elm bark beetles on crossings would allow breeders to rule out combinations that are most affected by this pest.

Phenotypic variation can be divided into two major components, one representing genetic factors and the other representing environmental influences or experimental errors (i.e., stochastic variation). Broad-sense heritability $\left(H^{2}\right)$ is the proportion of variance in a particular trait and population that is due to genetic components (Fig. 1). A common simplification in all genetic studies and models is to assume that all alleles and all genotypes act independently of each other. This type of model, known as an "additive model", does not allow for dominant or recessive effects and gene $\times$ gene interactions, even though they are known to be numerous. Broad-sense heritability can be further divided into additive genetic components and gene $\times$ gene interaction components (Fig. 1). The contribution of additive genetic components is termed narrow-sense heritability $\left(h^{2}\right)$. In other words, $h^{2}$ is the proportion of trait variance due to additive genetic factors, whereas $H^{2}$ is the proportion of trait variance due to all the genetic effects (Falconer \&

Mackay 1996). The difference between these two heritability parameters gives an estimate of the effect of interactions on a phenotype. If the difference is zero, it means there is no interaction and all phenotypic variations can be explained by additive components. A non-zero difference between the two heritability parameters suggests the role and degree of interaction effects on the phenotype (Bloom et al. 2013). Heritability estimates of vegetative budburst, height growth and resistance to $O$. novo-ulmi have not previously been reported for a breeding population of $U$. minor and U. pumila elms. In this study it is hypothesized that heritability estimates of previous traits will be high enough to justify selection and breeding. The study was designed to estimate genetic variation and inheritance of $U$. minor and $U$. minor $\times U$. pumila hybrids for budburst, growth and tolerance to $O$. novo-ulmi.

\section{Material and Methods}

\section{Plant material}

Ten clones - eight Ulmus minor (m) and two $U$. minor $\times U$. pumila $(\mathrm{mp})$ hybrids were used as parents for the mating design
Tab. 1 - Clones and number of controlled pollinated seedlings used in the partial diallel cross design. $(\mathrm{m})$ : Ulmus minor; $(\mathrm{mp})$ : U. minor $\times$ U. pumila; $(-)$ : controlled pollinated crosses not performed; (0): controlled pollination performed but no seedlings obtained.

\begin{tabular}{|c|c|c|c|c|c|c|c|c|c|c|}
\hline \multirow[b]{2}{*}{ Female } & \multicolumn{10}{|c|}{ Males } \\
\hline & 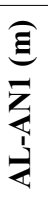 & $\underset{\underset{z}{\Xi}}{\stackrel{\Xi}{\Xi}}$ & $\begin{array}{l}\underset{3}{\Xi} \\
\frac{3}{3} \\
\frac{1}{\sigma}\end{array}$ & 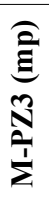 & 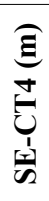 & 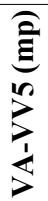 & 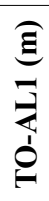 & 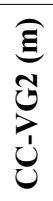 & 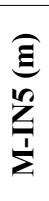 & 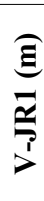 \\
\hline AL-AN1 (m) & - & 6 & 15 & 17 & 9 & - & - & - & - & - \\
\hline AL-JR1 (m) & - & - & 2 & 9 & 6 & 17 & - & - & - & - \\
\hline GR-AL3 (m) & - & - & - & 17 & 20 & 22 & 15 & - & - & - \\
\hline M-PZ3 (mp) & - & - & - & - & 29 & 23 & 6 & 11 & - & - \\
\hline $\mathrm{SE}-\mathrm{CT} 4(\mathrm{~m})$ & - & - & - & - & - & 17 & 38 & 0 & 10 & - \\
\hline VA-VV5 (mp) & - & - & - & - & - & - & 22 & 18 & 28 & 23 \\
\hline TO-AL1 (m) & 5 & - & - & - & - & - & - & 6 & 18 & 4 \\
\hline CC-VG2 (m) & 0 & 0 & - & - & - & - & - & - & 0 & 0 \\
\hline M-IN5 (m) & 0 & 0 & 0 & - & - & - & - & - & - & 0 \\
\hline V-JR1 (m) & 0 & 0 & 0 & 0 & - & - & - & - & - & - \\
\hline
\end{tabular}

(Tab. 1). Each clone comprised one plant. Parents were randomly selected from the elm clone bank population at the Forest Breeding Center in Puerta de Hierro, Madrid (see Appendix 1). This bank includes more than 200 Iberian elm clones, obtained through vegetative (root cuttings) or sexual reproduction from elms selected in the countryside according to their good sanitary status, diversity (geographical, ecological and genetic) and distinctive ornamental traits. The 10 clones selected were characterized through isozyme markers before crossing (Cogolludo-Agustín et al. 2000).

Selected clones were crossed in 2000 following a partial diallel cross design (Bridgewater 1992). Forty cross-combinations were planned (Tab. 1), but 13 failed to provide full-sib progeny (combinations marked " 0 " in Tab. 1) due to the presence of three previously undetected aborting $U$. minor individuals (CC-VG2, M-IN5 and V-JR1) (López-Almansa et al. 2004). Pollination was conducted through traditional tree breeding techniques using greenhouse-forced pollen (Fig. 2a) and isolation bags on trees (Mittempergher \& La Porta 1991). When a clone was used as female parent, the flowers were chosen on different branches of the same tree and bagged separately. Pollen from one male parent was used to pollinate the flowers of one or two bagged branches. To protect seeds from birds, bags were not removed from the branches until mature seeds had been collected. Isolated flowers were pollinated by inserting a syringe into the bag (Fig. 2b), after checking pollen viability by fluorochromatic reaction (Heslop-Harrison \& Heslop-Harrison 1970). Flowers in each bag were pollinated twice when possible, allowing four to five days between pollinations.

Seeds were sown outdoors in a mixture of sand, perlite and peat $(1: 1: 1)$ and one-yearold dormant seedlings were planted in a randomized two-block field design. Each block had one to six experimental units per cross, and each experimental unit (i.e., subsample) comprised three plants. The number of experimental units for each entry within each block was the same. The field design (Fig. 2c) was installed at the Center in Madrid. Spacing was $1.5 \mathrm{~m}$ between rows and $0.5 \mathrm{~m}$ between plants within rows. An elm line border was included to avoid side effects. To ensure plant growth, the plot was weeded annually, the soil was fertilized once a year (Osmocote $^{\odot}$ plus, Scotts, Australia) and plants were watered weekly in summer.

In 2000, ramets of six clones (AL-AN1, AL-JR1, GR-AL3, M-PZ3, TO-AL1, and VJR1) were obtained through root cuttings. Cuttings were obtained inside individual 2-1 pots containing a fine sandy loam texture soil and peat $(80: 20, v / v)$. Plants from the root stocks of the same clone were then 
Fig. 2 - Methods: (a) forced pollen sampling from greenhouse flowering twigs in February 2000; (b) controlled pollinations performed by insufflating pollen into isolation bags; (c) plantation of the experimental plot in March 2002; (d) tree growth assessment in October 2004;

(e) artificial inoculations with Ophiostoma novoulmi in May 2005; (f) leaf wilting assessment in July
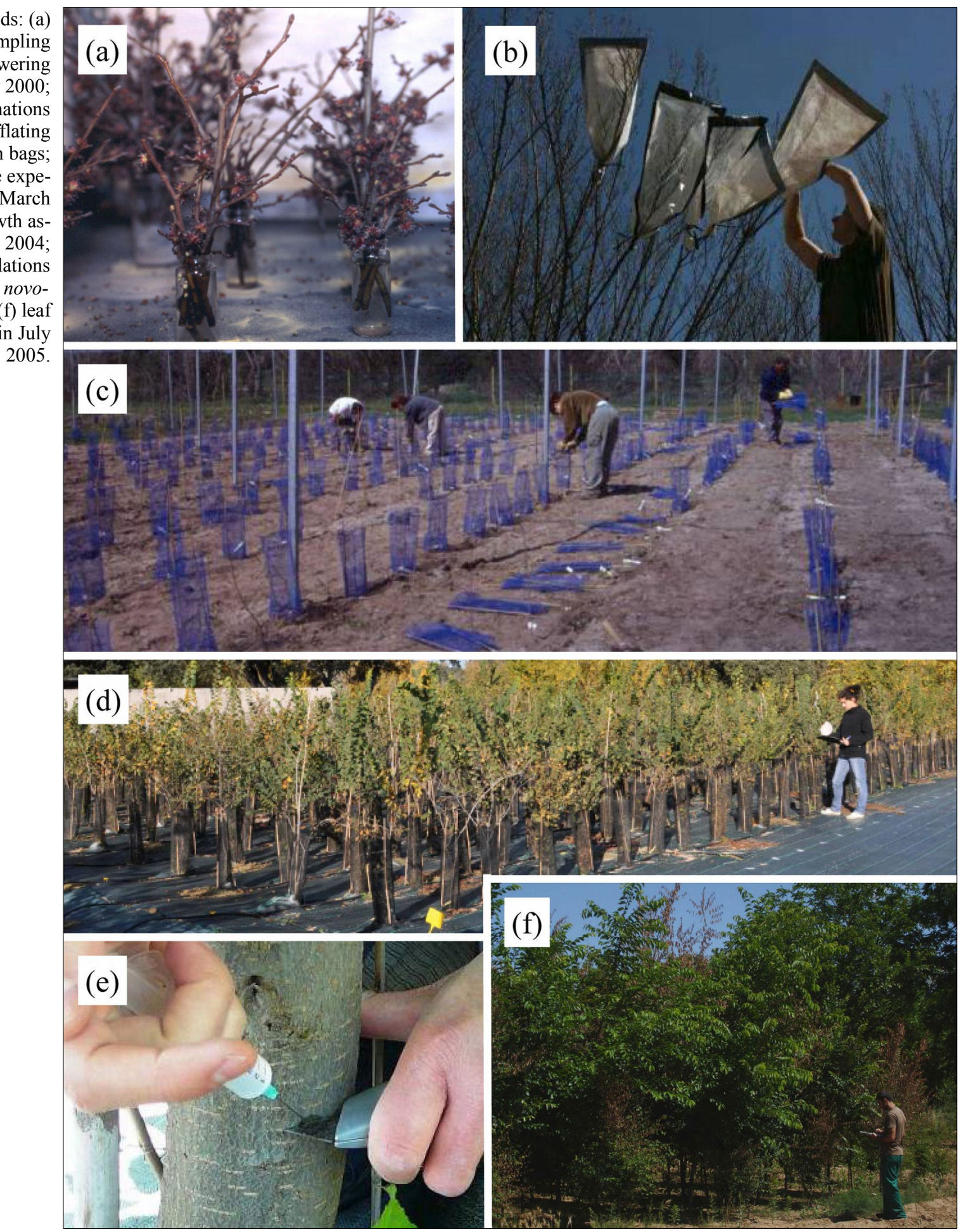

transplanted within the plot containing the cross-pollinated seedlings. At least seven ramets $($ mean $=12)$ per clone were transplanted randomly within the two blocks of the field design. Additionally, seeds (half-sib progeny) from seven open pollinated clones (AL-AN1, AL-JR1, GR-AL3, M-PZ3, TOAL1, SE-CT4, and VA-VV5) were collected in 2000, sown in the same conditions and planted within the plot. At least 15 open pol- linated seedlings $($ mean $=18)$ per clone were planted.

Tree growth, budburst, flowering and fructification assessments

All seedlings and ramets shown in Tab. 2 were assessed. Tree growth was recorded by measuring tree height in October 2004 (Fig. $2 d$ ) and dividing by tree age. Phenology was assessed from February 7 to April 92005.
Date of vegetative budburst was taken on 30 buds per tree. Bud development was assessed weekly as follows (Santini et al. 2004): $1=$ dormant buds; $2=$ swollen buds, but scales closed; $3=$ bud scales open and extremities of the first leaf visible at the apex of the buds; $4=$ extremities of all leaves out; and $5=$ two or more leaves completely expanded. Flowering was quantitatively assessed on March 4 2005, when most stami- 
nal filaments had begun extending, from $0=$ no floral buds to $5=$ the whole crown showing floral buds. Fruit development was monitored macroscopically using 30 samaras per tree, when available.

\section{Resistance to Ophiostoma novo-ulmi and beetle wound incidence}

Plants smaller than $0.7 \mathrm{~m}$ or affected by natural infections were not inoculated. All other plants were inoculated on May $7^{\text {th }}$ 2005 (Fig. 2e). The number of seedlings and ramets inoculated is shown in Tab. 2. The pathogen, Ophiostoma novo-ulmi subsp. americana Brasier, was isolated in 2002 in Blacos (Soria, Spain; code SO-BL1) from an infected $U$. minor tree. This strain was selected because of its high virulence and in vitro growth $\left(5.8 \mathrm{~mm}^{-1 a y}{ }^{-1}\right.$ on MEA at $20^{\circ} \mathrm{C}$ - Solla et al. 2008). The inoculum consisted of a bud-cell suspension of the fungus grown in Tchernoff's medium (Tchernoff 1965). The suspension was centrifuged to eliminate the medium and then filtered, and the precipitate was adjusted in sterile distilled water to $10^{4}$ spores $\mathrm{ml}^{-1}$ (Martín et al. 2005). At midday, a transversal cut was made with a flame-sterilized scalpel blade in the sapwood of the trees, $8-10 \mathrm{~cm}$ above the soil surface, on the north side of each tree (Fig. 2e - Solla et al. 2005b). Two $0.1 \mathrm{ml}$ drops of bud-cell suspension were applied above the blade using a hypodermic syringe and the inoculum was immediately drawn into the xylem. The percentage of the crown showing wilting or death of the foliage was visually estimated 15, 30, 60 and 120 dpi (days post inoculation), using a $5 \%$ interval.

A single scolytid trap was installed about $300 \mathrm{~m}$ from the plots, as described by Solla $\&$ Gil (2003). The trap was checked weekly in 2005 . On June $15^{\text {th }}$ and $16^{\text {th }}$, two weeks after the peak of captured beetles, the number of trunk feeding grooves was quantified for each tree: $0=$ no beetle grooves present; $1=$ at least one beetle groove; $2=$ abundant beetle grooves on the trunk; and $3=$ abundant beetle grooves on the trunk and branches.

\section{Statistical analyses}

Mean values of traits were compared in two stages. Firstly, mean values were analysed at clone (ramet) and family levels. Secondly, the plant material was divided into groups according to the genealogy or propagation method: ramets, seedlings from open pollination (half-sib progenies) and seedlings from controlled pollination (full-sib progenies). The full-sib progenies were further divided according to parentage: crosses between clones of $U$. minor $(\mathrm{m} \times \mathrm{m}$ in Tab. 1 ), crosses between clones from $U$. minor $\times$ U. pumila $(\mathrm{mp} \times \mathrm{mp}$ in Tab. 1) and crosses between $\mathrm{m}$ and $\mathrm{mp}$ clones $(\mathrm{m} \times \mathrm{mp}$ and $\mathrm{mp} \times$ $\mathrm{m}$ in Tab. 1). Angular transformation of wilting percentages $(x)$ was performed to nor- malize data before statistical analysis $[y=$ $\left.(x / 100)^{1 / 2}\right]$. Vegetative budburst notations, plant growth and transformed wilting values were analyzed by multifactor ANOVA, considering the block and the plant entries as factors. Post-hoc Fisher's LSD tests were applied to compare averages at $P<0.05$ and $P$ $<0.01$.

Heritability estimates for vegetative budburst, plant growth and resistance to $O$. novo-ulmi were calculated in two different ways. Firstly, the regression coefficients between parent (ramets) means and offspring means were computed. Both "ramets $v s$ halfsib progenies" and "ramets vs full-sib progenies" relations were considered. Estimation of heritability by the parent-offspring (P-O) regression method is relatively free of genetic assumptions and is often recommended as an empirical and reliable method for estimating narrow-sense heritabilities $\left(h^{2}\right.$ - Falconer \& Mackay 1996). The standard error $(S E)$ for each $h^{2}$ estimate was calculated as (eqn. 1):

$$
S E\left[h_{P-O}^{2}\right]=\left(\frac{1-r_{P-O}^{2}}{n-2}\right)^{\frac{1}{2}}
$$

where $n$ is the number of controlled pollinated families. Secondly, we estimated variance components and respective standard errors after removing the parental genotypes from the datasets, and analyzed the controlled pollinated seedlings population via the restricted maximum likelihood (REML) method. REML analysis is currently the method of choice for estimating heritability and variance components, as it does not require a balanced design (Falconer \& Mackay 1996). Variance components for broad-sense heritability estimates were made under a random model by treating the variables family and block as random factors. Broad-sense heritability $\left(H^{2}\right)$ estimates were calculated on a single-plant basis via the following equation (Fehr 1987 - eqn. 2):

$$
H_{(\text {plant basis })}^{2}=\frac{\sigma_{g}^{2}}{\left(\sigma_{g}^{2}+\sigma_{e}^{2}\right)}
$$

where $\sigma_{\mathrm{g}}^{2}$ is the genetic variance and $\sigma_{\mathrm{e}}^{2}$ the experimental error variance. Broad-sense heritability estimates were calculated on a family mean basis using the equation (Fehr 1987 - eqn. 3 )

$$
H_{(\text {mean basis })}^{2}=\frac{\sigma_{g}^{2}}{\sigma_{g}^{2}+\left(\sigma_{e}^{2} / r\right)}
$$

where $r$ refers to the average number of seedlings for each family. Approximate $S E$ of the $H^{2}$ estimates were calculated as $S E$ $\left[H_{\text {(plant basis })}^{2}=S E\left(\sigma_{\mathrm{g}}^{2}\right) /\left(\sigma_{\mathrm{g}}^{2}+\sigma_{\mathrm{e}}^{2}\right)\right.$ and $S E\left[H^{2}\right.$ (mean basis $]=S E\left(\sigma_{\mathrm{g}}^{2}\right) /\left[\sigma_{\mathrm{g}}^{2}+\left(\sigma_{\mathrm{e}}^{2} / r\right)\right]$, respectively (Hallauer \& Miranda 1988, Nyquist 1991). Variance components for narrowsense heritability estimates were analyzed under a random model by treating the variables male, female, block and male $\times$ female interaction as random factors. Narrow-sense heritability estimates were calculated on a single-plant basis using the following equation (eqn. 4):

$$
h_{(\text {plantbasis })}^{2}=\frac{\sigma_{\text {add }}^{2}}{\sigma_{\text {add }}^{2}+\sigma_{\text {dom }}^{2}+\sigma_{e}^{2}}
$$

where (eqn. 5):

$$
\sigma_{\text {add }}^{2}=4 \cdot \frac{\sigma_{\text {males }}^{2}+\sigma_{\text {females }}^{2}}{2}
$$

and (eqn. 6):

$$
\sigma_{\text {dom }}^{2}=4 \cdot \sigma_{\text {males } \times \text { females }}^{2}
$$

(Hallauer \& Miranda 1988). The term $\sigma^{2}$. again refers to the experimental error variance, but unlike the case of broad-sense heritability formulas, $\sigma_{\mathrm{e}}^{2}$ is the experimental error excluding the additive and dominance genetic variances. Narrow-sense heritability estimates were calculated on a genotype mean basis using the equation (eqn. 7):

$$
h_{(\text {mean basis })}^{2}=\frac{\sigma_{\text {add }}^{2}}{\sigma_{\text {add }}^{2}+\sigma_{\text {dom }}^{2}+\left(\sigma_{e}^{2} / r\right)}
$$

Approximate standard errors (SE) of the $h^{2}$ estimates were calculated using the formulas $S E\left[h_{\text {(plant basis })}^{2}=4 S E\left(\sigma_{\text {males }}^{2}\right) /\left(\sigma_{\text {add }}^{2}+\sigma_{\text {dom }}^{2}+\right.\right.$ $\left.\sigma_{\mathrm{e}}^{2}\right)$ and $S E\left[h^{2}\right.$ (mean basis $\left.)\right]=4 S E\left(\sigma_{\text {males }}^{2}\right) /\left[\sigma_{\text {add }}^{2}\right.$ $\left.+\sigma_{\text {dom }}^{2}+\left(\sigma_{\mathrm{e}}^{2} / r\right)\right]$ (Hallauer \& Miranda 1988).

Genetic gains $(\Delta G)$ were obtained from $\Delta G$ $=h^{2}$ (mean basis) $\times($ selection differential), where selection differential is the difference between the mean value of the trait of selected individuals and the mean value of the trait of all individuals (White et al. 2007), including those selected. The mean value of the trait of all the individuals was obtained from measurements of this trait in all the open pollinated families $(\mathrm{N}=7)$.

Pearson correlation coefficients (phenotypic $r_{\mathrm{p}}$ ) among values of vegetative budburst, annual height growth and transformed percentages of wilting were obtained. Statistics were performed using StatgRaPhICS ${ }^{\circledR}$ Plus v. 10 , and REML analysis and variance components were obtained using the mixed procedure of GenSTAT ${ }^{\circledR}$ v. 8.

\section{Results}

At age five years, only 30 out of 491 seedlings $(6.1 \%)$ and 10 out of 58 ramets $(17.2 \%)$ produced flowers, accounting for $7.3 \%$ of total trees (Tab. 2). Two out of six $U$. minor $\times(U$. minor $\times U$. pumila $)$ progenies included flowering trees (mean $=2.0 \%$ ). However, all seven $(U$. minor $\times U$. pumila $) \times$ $U$. minor progenies produced at least one flowering tree $($ mean $=10.2 \%)$. Approximately $14.2 \%$ of trees had trunk feeding grooves caused by elm bark beetles (Tab. 2).

Mean leaf wilting percentages $( \pm$ SD) 15 , 30,60 and 120 dpi were $19 \pm 20,34 \pm 25$, 
Tab. 2 - Mean values of five traits measured on ramets, open pollinated (op) seedlings, and controlled pollinated seedlings from crosses (fe male $\times$ male) between Ulmus minor (AL-AN1, AL-JR1, GR-AL3, SE-CT4, TO-AL1, CC-VG2, M-IN5 and V-JR1) and U. minor $\times U$. pumila (M-PZ3 and VA-VV5) clones. Different letters indicate differences between means $(P<0.01)$. (a): trees with beetle feeding grooves on trunk or branches; (b): assessed on April 92005 on a scale from 1= dormant buds to $5=$ two or more leaves completely expanded; (c): as sessed on July 72005,60 days after inoculations with Ophiostoma novo-ulmi.

\begin{tabular}{|c|c|c|c|c|c|c|}
\hline Plant material & No. trees & $\begin{array}{l}\text { Flowering } \\
\text { trees (\%) }\end{array}$ & $\begin{array}{c}\text { Beetle affected } \\
\text { trees }(\%)^{\mathrm{a}}\end{array}$ & $\begin{array}{l}\text { Vegetative } \\
\text { budburst }^{\mathbf{b}}\end{array}$ & $\begin{array}{c}\text { Annual height } \\
\text { growth (cm) }\end{array}$ & $\begin{array}{c}\text { Leaf wilting } \\
(\%)^{\mathbf{c}}\end{array}$ \\
\hline AL-AN1 ramets & 7 & 0.0 & 0.0 & $4.6^{\text {bcde }}$ & $21.6^{\mathrm{a}}$ & $80.0^{\mathrm{e}}$ \\
\hline AL-AN1 op & 11 & 0.0 & 0.0 & $4.4^{\text {bcde }}$ & $32.2^{\mathrm{ab}}$ & $49.1^{\mathrm{e}}$ \\
\hline AL-AN1 × AL-JR1 & 6 & 33.3 & 16.7 & $4.8^{\mathrm{cde}}$ & $37.3^{\mathrm{bc}}$ & $23.3^{\mathrm{abcd}}$ \\
\hline AL-AN1 $\times$ GR-AL3 & 15 & 0.0 & 0.0 & $4.4^{\text {bcde }}$ & $40.4^{\mathrm{bcd}}$ & $35.0^{\text {bcde }}$ \\
\hline AL-AN1 × M-PZ3 & 17 & 0.0 & 17.6 & $4.1^{b c}$ & $45.0^{\text {bcde }}$ & $38.1^{\text {cde }}$ \\
\hline AL-AN1 $\times$ SE-CT4 & 9 & 0.0 & 11.1 & $4.8^{\mathrm{de}}$ & $35.1^{\mathrm{abc}}$ & $41.3^{\mathrm{de}}$ \\
\hline AL-JR1 ramets & 11 & 0.0 & 9.1 & $4.9^{\mathrm{e}}$ & $25.8^{\mathrm{a}}$ & $75.0^{\mathrm{e}}$ \\
\hline AL-JR1 op & 12 & 16.7 & 25.0 & $4.1^{\mathrm{bcd}}$ & $62.3^{\text {ef }}$ & $36.3^{\text {cde }}$ \\
\hline AL-JR1 $\times$ GR-AL3 & 2 & 0.0 & 0.0 & $5.0^{\text {cde }}$ & $14.0^{\mathrm{a}}$ & $20.0^{\mathrm{ab}}$ \\
\hline AL-JR1 × M-PZ3 & 9 & 0.0 & 44.4 & $4.8^{\mathrm{de}}$ & $58.5^{\text {def }}$ & $35.0^{\text {bcde }}$ \\
\hline AL-JR1 $\times$ SE-CT4 & 6 & 0.0 & 16.7 & $4.4^{\text {bcde }}$ & $38.3^{\mathrm{abcd}}$ & $30.0^{\text {abcde }}$ \\
\hline AL-JR1 × VA-VV5 & 17 & 5.9 & 17.6 & $4.6^{\mathrm{cde}}$ & $53.1^{\mathrm{def}}$ & $43.2^{\mathrm{e}}$ \\
\hline GR-AL3 ramets & 13 & 0.0 & 0.0 & $5.0^{\text {cde }}$ & $24.0^{\mathrm{a}}$ & $2.8^{\mathrm{a}}$ \\
\hline GR-AL3 op & 10 & 0.0 & 50.0 & $4.9^{\mathrm{e}}$ & $84.0^{\text {ef }}$ & $55.0^{\mathrm{ab}}$ \\
\hline GR-AL3 $\times$ M-PZ3 & 17 & 0.0 & 23.5 & $4.3^{\text {bcde }}$ & $45.9^{\text {bcde }}$ & $20.3^{\mathrm{ab}}$ \\
\hline GR-AL3 × SE-CT4 & 20 & 25.0 & 40.0 & $4.6^{\mathrm{cde}}$ & $58.5^{\text {ef }}$ & $16.5^{\mathrm{a}}$ \\
\hline GR-AL3 × VA-VV5 & 22 & 0.0 & 9.1 & $3.8^{\mathrm{ab}}$ & $49.1^{\text {cde }}$ & $14.5^{\mathrm{a}}$ \\
\hline GR-AL3 × TO-AL1 & 15 & 6.7 & 0.0 & $4.8^{\mathrm{e}}$ & $33.4^{\mathrm{ab}}$ & $32.2^{\text {bcde }}$ \\
\hline M-PZ3 ramets & 12 & 75.0 & 16.7 & $2.9^{\mathrm{a}}$ & $75.0^{f}$ & $28.8^{\text {abcd }}$ \\
\hline M-PZ3 op & 24 & 4.2 & 12.5 & $4.2^{b c}$ & $48.5^{\mathrm{cde}}$ & $24.0^{\mathrm{abc}}$ \\
\hline $\mathrm{M}-\mathrm{PZ} 3 \times \mathrm{SE}-\mathrm{CT} 4$ & 29 & 3.4 & 17.4 & $4.8^{\mathrm{e}}$ & $50.0^{\text {cde }}$ & $19.1^{\mathrm{ab}}$ \\
\hline M-PZ3 × VA-VV5 & 23 & 0.0 & 17.4 & $4.1^{b c}$ & $47.3^{\text {cde }}$ & $17.7^{\mathrm{a}}$ \\
\hline M-PZ3 × TO-AL1 & 6 & 16.7 & 50.0 & $3.1^{\mathrm{a}}$ & $65.3^{\text {ef }}$ & $48.3^{\mathrm{e}}$ \\
\hline $\mathrm{M}-\mathrm{PZ} 3 \times \mathrm{CC}-\mathrm{VG} 2$ & 11 & 9.1 & 18.2 & $4.4^{\text {bcde }}$ & $55.0^{\text {def }}$ & $23.8^{\text {abcd }}$ \\
\hline SE-CT4 op & 14 & 0.0 & 0.0 & 4.7 bcde & $28.0^{\mathrm{ab}}$ & $18.8^{\mathrm{a}}$ \\
\hline SE-CT4 × VA-VV5 & 17 & 5.9 & 5.9 & $4.4^{\text {bcde }}$ & $39.2^{\mathrm{abcd}}$ & $40.0^{\text {de }}$ \\
\hline SE-CT4 $\times$ TO-AL1 & 38 & 0.0 & 0.0 & $4.5^{\mathrm{cde}}$ & $34.6^{\mathrm{ab}}$ & $38.8^{\mathrm{de}}$ \\
\hline SE-CT4 × M-IN5 & 10 & 0.0 & 0.0 & $4.0^{\mathrm{bc}}$ & $39.9^{\text {abcd }}$ & $26.7^{\text {abcde }}$ \\
\hline VA-VV5 op & 2 & 0.0 & 0.0 & $5.0^{\text {cde }}$ & $75^{f}$ & $10.0^{\mathrm{abc}}$ \\
\hline VA-VV5 $\times$ TO-AL1 & 22 & 4.5 & 18.2 & $4.9^{\mathrm{e}}$ & $44.8^{\text {bcde }}$ & $25.2^{\mathrm{abcd}}$ \\
\hline VA-VV5 $\times$ CC-VG 2 & 18 & 22.2 & 11.1 & $4.5^{\text {bcde }}$ & $65.3^{f}$ & $17.0^{\mathrm{ab}}$ \\
\hline VA-VV5 $\times$ M-IN5 & 28 & 14.3 & 28.6 & $4.7^{\mathrm{de}}$ & $62.1^{\mathrm{f}}$ & $15.0^{\mathrm{a}}$ \\
\hline VA-VV5 $\times$ V-JR1 & 23 & 13.0 & 17.4 & $4.8^{\mathrm{e}}$ & $56.9^{\text {def }}$ & $17.9^{\mathrm{ab}}$ \\
\hline TO-AL1 ramets & 7 & 14.3 & 14.3 & $3.7^{\mathrm{ab}}$ & $44.7^{\text {bcde }}$ & $40.0^{\mathrm{cd}}$ \\
\hline TO-AL1 op & 5 & 20.0 & 20.0 & $4.8^{\text {cde }}$ & $37.6^{\mathrm{abcd}}$ & $30.0^{\text {abcde }}$ \\
\hline TO-AL1 × AL-AN1 & 5 & 0.0 & 40.0 & $4.7^{\mathrm{cde}}$ & $44.2^{\text {bcde }}$ & $20.0^{\mathrm{ab}}$ \\
\hline TO-AL1 $\times$ CC-VG2 & 6 & 0.0 & 0.0 & $4.8^{\mathrm{cde}}$ & $47.0^{\text {bcde }}$ & $43.3^{\text {de }}$ \\
\hline TO-AL1 $\times$ M-IN5 & 18 & 5.6 & 0.0 & $4.6^{\text {cde }}$ & $36.3^{\mathrm{abc}}$ & $22.1^{\mathrm{abc}}$ \\
\hline TO-AL1 $\times$ V-JR1 & 4 & 0.0 & 0.0 & $5.0^{\mathrm{de}}$ & $40.0^{\mathrm{abc}}$ & $7.0^{\mathrm{ab}}$ \\
\hline V-JR1 ramets & 8 & 0.0 & 0.0 & $4.7^{\mathrm{cde}}$ & $24.1^{\mathrm{ab}}$ & $40.0^{\text {de }}$ \\
\hline Average & 17 & 7.3 & 14.2 & 4.4 & 45.5 & 37.1 \\
\hline
\end{tabular}

$37 \pm 26$ and $33 \pm 31$, respectively. Because vegetative budburst on April 9 and wilting 60 dpi provided the highest F-ratio values in the ANOVAs (results not shown), these measurements were used for further statistical analyses. Means for vegetative budburst, annual height growth and disease response for progeny combinations differed at a probability of $99 \%$ for each trait (Tab. 2). Cross-pollinated families with VA-VV5 and M-PZ3 as female parent had the highest annual height growth rates. Lowest height growth occurred when SE-CT4 was female parent (Tab. 3). Height growth was greater when GR-AL3 and AL-JR1 were used as fe- male rather than male parents (Tab. 3). Controlled pollinated families of $U$. minor showed fast growth when CC-VG2 was used as male parent and low susceptibility when M-IN5 was the male parent (Tab. 3). Most crosses resulted in progenies with similar traits to their parents or intermediate traits. However, AL-AN1 $\times$ GR-AL3 and AL-JR1 $\times$ GR-AL3 showed heterosis in annual height growth, and AL-AN1 $\times$ AL-JR1, MPZ3 $\times$ TO-AL1, TO-AL1 $\times$ AL-AN1 and TO-AL1 $\times$ V-JR1 showed heterosis in resistance to O. novo-ulmi (Tab. 2). Several elm trees obtained from GR-AL3 $\times$ SE-CT4, M$\mathrm{PZ3} \times \mathrm{CC}-\mathrm{VG} 2$ and VA-VV5 $\times$ M-IN5 crossings showed growth rates above $80 \mathrm{~cm}$ $\mathrm{yr}^{-1}$ and wilting levels under $20 \%$. Some ramets were especially heterogeneous for certain traits, i.e., M-PZ3 for wilting and TO-AL1 for growth (Tab. 2).

Ulmus minor ramets showed earlier mean vegetative budburst, lower mean height growth rates and higher mean wilting values than $U$. minor $\times U$. pumila ramets $(P<0.05$ - Tab. 4). Differences in traits between $U$. minor and $U$. minor $\times U$. pumila open pollinated progenies were statistically significant only for leaf wilting, and $U$. minor $\times U$. pumila was more resistant than $U$. minor ( $P$ $<0.05$ - Tab. 4). A notable result of con- 
Tab. 3 - Mean values of annual height growth and leaf wilting (60 days after inoculations with Ophiostoma novo-ulmi) of cross-pollinated families with different female and male parents. Within the same column, different letters indicate differences between means $(P<$ 0.05). (m): Ulmus minor; (mp): U. minor $\times$ U. pumila.

\begin{tabular}{lcccc}
\hline \multirow{2}{*}{ Parent } & \multicolumn{2}{c}{ Families with a female parent } & \multicolumn{2}{c}{ Families with a male parent } \\
\cline { 2 - 5 } & $\begin{array}{c}\text { Annual height } \\
\text { growth (cm) }\end{array}$ & $\begin{array}{c}\text { Leaf } \\
\text { wilting (\%) }\end{array}$ & $\begin{array}{c}\text { Annual height } \\
\text { growth (cm) }\end{array}$ & $\begin{array}{c}\text { Leaf } \\
\text { wilting (\%) }\end{array}$ \\
\hline AL-AN1 (m) & $40.7^{\mathrm{a}}$ & $35.9^{\mathrm{bc}}$ & $42.2^{\mathrm{abcd}}$ & $12.7^{\mathrm{abc}}$ \\
AL-JR1 (m) & $49.5^{\mathrm{b}}$ & $37.9^{\mathrm{bc}}$ & $37.3^{\mathrm{a}}$ & $16.3^{\mathrm{abc}}$ \\
GR-AL3 (m) & $47.8^{\mathrm{b}}$ & $19.1^{\mathrm{a}}$ & $37.3^{\mathrm{a}}$ & $29.7^{\mathrm{abc}}$ \\
M-PZ3 (mp) & $51.3^{\mathrm{bc}}$ & $22.0^{\mathrm{a}}$ & $48.1^{\mathrm{bc}}$ & $20.2^{\mathrm{bc}}$ \\
SE-CT4 (m) & $36.6^{\mathrm{a}}$ & $37.9^{\mathrm{c}}$ & $49.5^{\mathrm{bc}}$ & $25.0^{\mathrm{a}}$ \\
VA-VV5 (mp) & $57.2^{\mathrm{c}}$ & $19.7^{\mathrm{a}}$ & $47.4^{\mathrm{bc}}$ & $21.5^{\mathrm{abc}}$ \\
TO-AL1 (m) & $38.9^{\mathrm{a}}$ & $27.7^{\mathrm{ab}}$ & $39.4^{\mathrm{a}}$ & $26.4^{\mathrm{c}}$ \\
CC-VG2 (m) & - & - & $58.9^{\mathrm{d}}$ & $25.7^{\mathrm{abc}}$ \\
M-IN5 (m) & - & - & $49.9^{\mathrm{bc}}$ & $18.7^{\mathrm{a}}$ \\
V-JR1 (m) & - & - & $53.2^{\mathrm{cd}}$ & $17.8^{\mathrm{ab}}$ \\
\hline
\end{tabular}

Tab. 4 - Mean values of five traits measured on ramets and open pollinated progenies (op). Different letters indicate differences between means $(P<0.05)$. Values within parenthesis correspond to the range. (a): trees with beetle feeding grooves on trunk or branches; (b) assessed on April $9^{\text {th }} 2005$ on a scale from $1=$ dormant buds to $5=$ two or more leaves completely expanded; (c) assessed on July $7^{\text {th }} 2005,60$ days after inoculations with Ophiostoma novo-ulmi; $(\mathrm{m})$ : Ulmus minor; $(\mathrm{mp})$ : U. minor $\times$ U. pumila.

\begin{tabular}{|c|c|c|c|c|c|c|}
\hline $\begin{array}{l}\text { Plant } \\
\text { material }^{\mathrm{a}}\end{array}$ & $\begin{array}{l}\text { No. } \\
\text { trees }\end{array}$ & $\begin{array}{c}\text { Flowering } \\
\text { trees }(\%)\end{array}$ & $\begin{array}{c}\text { Beetle } \\
\text { affected } \\
\text { trees }(\%)^{\mathbf{b}}\end{array}$ & $\begin{array}{l}\text { Vegetative } \\
\text { budburst }^{\mathrm{c}}\end{array}$ & $\begin{array}{l}\text { Annual height } \\
\text { growth (cm) }\end{array}$ & $\begin{array}{c}\text { Leaf } \\
\text { wilting }(\%)^{d}\end{array}$ \\
\hline nets & 46 & 2.2 & 4.3 & $4.1^{\mathrm{bc}} \quad(1-5)$ & $27.7^{\mathrm{a}}$ & $46.4^{\mathrm{d}}(5-100)$ \\
\hline $\mathrm{mp}$ ramets & 12 & 75.0 & 75.0 & $2.9^{\text {a }} \quad(2-4)$ & $73.3^{d}(36-102)$ & $28.8^{\mathrm{ab}} \quad(0-70)$ \\
\hline m op & 52 & 5.7 & 17.3 & $4.5^{\mathrm{bc}}(2-5)$ & $45.3^{\text {bc }} \quad(7-95)$ & $38.0^{\mathrm{cd}}(0-100)$ \\
\hline $\mathrm{mp}$ op & 26 & 3.8 & 3.8 & $4.2^{\mathrm{bc}}(1-5)$ & $50.5^{\text {bc }}(15-80)$ & $22.9^{\mathrm{ab}} \quad(0-60)$ \\
\hline
\end{tabular}

Tab. 5 - Heritability estimates $( \pm \mathrm{SE})$ of Ulmus minor and $U$. pumila hybrids for vegetative budburst, height growth, and resistance to Ophiostoma novo-ulmi obtained from regression between ramets and open pollinated families, and between ramets and controlled pollinated families. (a): average values of two $x$ and $y$ clones were correlated to their respective $x \times y$ families.

\begin{tabular}{lccc}
\hline Plant material & $\begin{array}{c}\text { Vegetative } \\
\text { budburst }\end{array}$ & $\begin{array}{c}\text { Height } \\
\text { growth }\end{array}$ & $\begin{array}{c}\text { Disease } \\
\text { resistance }\end{array}$ \\
\hline Ramets $v s$ open pollinated families & $0.38 \pm 0.34$ & $0.41 \pm 0.32$ & $0.13 \pm 0.32$ \\
Ramets $v s$ controlled pollinated families ${ }^{a}$ & $0.64 \pm 0.18$ & $0.69 \pm 0.17$ & $0.36 \pm 0.35$ \\
\hline
\end{tabular}

Tab. 6 - Variance components and heritability estimates $( \pm \mathrm{SE})$ in the broad $\left(H^{2}\right)$ and narrow $\left(h^{2}\right)$ sense of Ulmus minor and U. pumila hybrids for vegetative budburst, height growth, and resistance to Ophiostoma novo-ulmi. (a): the average number of seedlings for each family was assumed to be $r=8$.

\begin{tabular}{llcc}
\hline $\begin{array}{l}\text { Variance components and } \\
\text { heritability estimates }\end{array}$ & $\begin{array}{c}\text { Vegetative } \\
\text { budburst }\end{array}$ & $\begin{array}{c}\text { Height } \\
\text { growth }\end{array}$ & $\begin{array}{c}\text { Disease } \\
\text { resistance }\end{array}$ \\
\hline$\sigma_{\mathrm{g}}^{2} \pm \mathrm{SE}$ & $0.0602 \pm 0.0406$ & $48.2 \pm 26.7$ & $81.3 \pm 25.1$ \\
$\sigma_{\mathrm{e}}^{2}$ & 0.9030 & 456.2 & 270.2 \\
$H^{2}$ single-plant basis $\pm \mathrm{SE}$ & $0.06 \pm 0.04$ & $0.10 \pm 0.05$ & $0.23 \pm 0.07$ \\
$H^{2}$ family mean basis $\pm \mathrm{SE}$ & $0.35 \pm 0.23$ & $0.46 \pm 0.25$ & $0.71 \pm 0.22$ \\
$\sigma_{\text {males }}^{2} \pm \mathrm{SE}$ & $0.0366 \pm 0.011$ & $0.0 \pm 3.8$ & $9.1 \pm 7.1$ \\
$\sigma_{\text {females }}^{2}$ & 0.0064 & 32.0 & 23.3 \\
$\sigma_{\text {males } \times \text { females }}^{2}$ & 0.0669 & 48.7 & 0.0 \\
$\sigma_{\text {add }}^{2}$ & 0.0860 & 64.0 & 64.8 \\
$\sigma_{\text {dom }}^{2}$ & 0.2676 & 194.8 & 0.0 \\
$\sigma_{\mathrm{e}}^{2}$ & 0.3504 & 47.5 & 412.1 \\
$h^{2}$ single-plant basis $\pm \mathrm{SE}$ & $0.12 \pm 0.06$ & $0.21 \pm 0.05$ & $0.14 \pm 0.06$ \\
$h^{2}$ family mean basis $\pm \mathrm{SE}$ & $0.22 \pm 0.11$ & $0.24 \pm 0.06$ & $0.56 \pm 0.24$ \\
\hline
\end{tabular}

trolled pollinated seedlings was the leaf wilting values obtained depending on whether the male parent was $U$. minor or U. minor $\times$ U. pumila (21.5 and $30.6 \%$, respectively). Resistance was higher when $U$. minor was used as male parent $(P<0.05)$.

Heritability estimates from the regression (Tab. 5) and analysis of variance (Tab. 6) methods ranged from 0.13 to 0.69 and 0.06 to 0.71 , respectively. Disease resistance heritability values were higher when estimated 60 dpi than 15, 30 or 120 dpi (results not shown). Expected genetic gains for height by selection in progenies from the M-PZ3 $\times$ TO-AL1 and VA-VV5 $\times$ CC-VG2 crosscombinations would be 3.07 and $3.07 \mathrm{~cm}$, respectively. Expected genetic gains to reduce leaf wilting by selection in progenies from the M-PZ3 $\times$ SE-CT4, VA-VV5 $\times$ MIN5 and VA-VV5 $\times$ V-JR1 cross-combinations would be $7.16,9.46$ and $7.83 \%$, respectively.

Annual height was phenotypically related to vegetative budburst, as budburst occurred earlier in seedlings with low rather than high growth rates $(P=0.0007$ - Tab. 7). Wilting percentage was negatively related to early budburst $(P<0.0001)$. Other significant relations among the controlled pollinated seedlings included percentage of flowering trees and annual height growth $\left(r_{\mathrm{p}}=0.44 ; P=\right.$ $0.0042)$, percentage of flowering trees and vegetative budburst $\left(r_{\mathrm{p}}=-0.53 ; P=0.0004\right)$, and percentage of beetle affected-trees and annual height growth $\left(r_{\mathrm{p}}=0.60 ; P<0.0001\right)$.

\section{Discussion}

To our knowledge, this is the first study to report heritability values and non-additive genetic variances of vegetative budburst, height growth and resistance to $O$. novoulmi in a breeding population of elms. Although the breeding of DED resistant elms began in the Netherlands in 1928 and the United States in 1933 (Mittempergher \& Santini 2004), little is known about inheritance of DED resistance in elms (Venturas et al. 2014). Genetically based resistance of trees to other forest diseases, such as poplar leaf rust (Lefevre et al. 1994), birch rust (Helander et al. 1998), Armillaria root rot (Zas et al. 2007) and pitch canker (Vivas et al. $2012 b$ ), suggests that breeding trees for resistance is possible. In the Ulmus genus, the response of backcross hybrids of $U$. pumila, $U$. japonica and U. rubra hybrids to inoculation with $O$. novo-ulmi has been reported (Lester \& Smalley 1972a, 1972b, 1972c), although heritability values were not quantified. Within a U. minor population, narrowsense heritability for wilting percentages was 0.54 (Venturas et al. 2014). Heritability values reported here confirm the hypothesis that vegetative budburst, height growth and DED resistance are genetically controlled.

Our first assessments of height growth, 
Tab. 7 - Phenotypic correlations (above the diagonal) between traits assessed in Ulmus minor and $U$. minor $\times U$. pumila controlled pollinated seedlings. (a): indicates significance at $P<0.001$.

\begin{tabular}{cccc}
\hline & $\begin{array}{c}\text { Annual height } \\
\text { growth }\end{array}$ & $\begin{array}{c}\text { Vegetative } \\
\text { budburst }\end{array}$ & $\begin{array}{c}\text { Leaf } \\
\text { wilting }\end{array}$ \\
\hline $\begin{array}{c}\text { Annual height } \\
\text { growth }\end{array}$ & $\mathrm{x}$ & $-0.26^{\mathrm{a}}$ & 0.06 \\
\hline $\begin{array}{c}\text { Vegetative } \\
\text { budburst }\end{array}$ & - & $\mathrm{x}$ & $-0.17^{\mathrm{a}}$ \\
\hline $\begin{array}{c}\text { Leaf } \\
\text { wilting }\end{array}$ & - & - & $\mathrm{x}$ \\
\hline
\end{tabular}

vegetative budburst and disease resistance in the controlled pollinated progenies were based on plant means. The primary functions of heritability estimates on a single-plant basis are to predict genetic progress through phenotypic selection and provide the relative magnitude of the genetic basis of height growth, vegetative budburst and disease resistance. However, the selection of families is probably based on family means and therefore the appropriate heritability for predicting genetic gain is the ratio of the variance component due to families to total phenotypic variance among family means, i.e., family mean heritability.

The estimates of heritability for resistance reported here are probably conservative due to the moderate levels of wilting obtained. The cell density used in the inoculum, lower than the density generally used in resistance tests for breeding purposes $\left(=10^{6}\right.$ conidia $\mathrm{ml}^{-1}$ - Santini et al. 2005, Solla et al. 2005a), was chosen to avoid high mortality. If we had observed a wider range of wilt symptoms, the genetic variability would have been readily expressed and the heritability values would probably have been higher (Strong et al. 1993, Le Cocq et al. 2005). We acknowledge that the number of replicates should have been higher, but unfortunately some clones used for the diallel design, coded CC-VG2, M-IN5 and V-JR1 and later characterized as female-sterile trees (LópezAlmansa et al. 2003, 2004), provided no seeds.

Ulmus minor flushes earlier in spring than other European elms (Richens 1983) and $U$. pumila flushes even earlier, at least in the conditions in Madrid. However, vegetative budburst occurred later in $U$. minor $\times U$. pumila than in $U$. minor ramets. This finding must be considered with caution, as the $U$. minor $\times U$. pumila sample was constituted by just one clone (M-PZ3). The late vegetative budburst in $U$. minor $\times U$. pumila hybrids could be related to the fact that hybrid ramets have greater fruit production than $U$. minor ramets. In the clonal bank at Puerta de Hierro Forest Breeding Center, it was observed that vegetative budburst is generally delayed if elms have abundant samara production, probably because of the energy cost required for fruit production. The significant relation observed between the percentage of flowering and late vegetative budburst could support this hypothesis. This relation would prevent proper comparison of budburst values between elms at a different juvenile or adult stage.

The negative association between vegetative budburst date and plant height, confirming earlier studies (Lester \& Smalley 1972c), should be considered with caution. Low trees, with buds close to soil level, would be exposed to higher temperatures during the day due to soil irradiation and would therefore flush earlier than taller trees (Zürcher 1986). Considering only trees taller than $1.5 \mathrm{~m}$, unaffected by soil irradiation, the phenotypic relation between vegetative budburst and plant height is not significant $\left(r_{\mathrm{p}}=\right.$ $0.09 ; P>0.1)$. Similar findings on the phenotypic relations between vegetative budburst and susceptibility to DED have been reported (Lester \& Smalley 1972c, Ghelardini \& Santini 2009). This relation seems to be independent of tree height, as the same calculation made for trees above $1.5 \mathrm{~m}$ still shows significance $\left(r_{\mathrm{p}}=-0.15 ; P=0.0061\right)$. Elms with early vegetative budburst could be more resistant because they may develop latewood earlier than elms with delayed budburst. Early latewood formation has been related to DED resistance (Pope 1943, Solla \& Gil 2002), as small diameter vessels and pits are thought to compartmentalize the disease better and be less vulnerable to cavitation than large diameter vessels and pits (Solla \& Gil 2002, Martín et al. 2009, Martín et al. 2013).

The high frequency of beetle feeding grooves in elms with $U$. minor $\times U$. pumila as a parent may be related to the higher growth their greater attractiveness to beetles. It would be interesting to test this hypothesis when all trees have reached larger size and maturity.

For most purposes, fast growth of elms is highly desirable (Heybroek 1957). However, one difficulty of this is that fast-growing trees often show high susceptibility to $O$. novo-ulmi (Lester \& Smalley 1972c, Solla et al. 2005b), although this relation is not unirates found in these individuals and not to versal (Heybroek 1957, Solla et al. 2005a), as confirmed here. Annual growth quantification of seedlings in the juvenile stage is sometimes erratic. Moderate growth in youth may be followed by subsequent fast growth, whereas fast growth in youth may later decline. Long-term field trials would be required to properly quantify this trait. Breeders should take advantage of height growth heterosis and select the most appropriate combination. Heterosis was observed in elm growth in crosses where $U$. glabra and $U$. wallichiana were used as parent trees (Heybroek 1957), as height was $50 \%$ greater in progenies than in parents.

Response to DED varied significantly depending on whether $U$. minor $\times U$. pumila was used as female or male parent. The higher resistance of $(U$. minor $\times U$. pumila $)$ $\times U$. minor hybrids may result from using $U$. minor $\times U$. pumila as female parent. This combination could contain more germplasm from $U$. pumila than $U$. minor $\times(U$. minor $\times$ $U$. pumila), although this statement needs experimental support. The result obtained is of practical interest in breeding programmes because it provides information about the optimal choice for obtaining resistant progenies. As crosses are time-consuming, choosing the option of $(U$. minor $\times U$. pumila $) \times$ $U$. minor rather than $U$. minor $\times(U$. minor $\times$ $U$. pumila) would save both time and effort. Breeding strategies should therefore concentrate on combinations such as M-PZ3 $\times$ SECT4, VA-VV5 $\times$ TO-AL1, VA-VV5 $\times$ MIN5 and VA-VV5 $\times$ V-JR1. The high genetic variation of height growth and disease response within some $(U$. minor $\times U . p u$ mila) $\times U$. minor combinations (e.g., VAVV5 $\times$ TO-AL1) may be of great value in advanced stages of breeding. The timing of vegetative budburst should also be taken into account: in sites with a severe continental climate or a large population of defoliating insects, care must be taken with combinations that result in seedlings with early budburst.

In this study, it was possible to obtain satisfactory gains for the three traits assessed. Estimated gains for growth and tolerance to DED were promising and, as far as we know, they are probably the first to be reported in an elm population. Further re-selection of other elm trees for height and disease resistance will improve the existing population, allowing a considerable increase in the predicted gains.

\section{Conclusions}

Evidence on the effect of genes from $U$. pumila in terms of resistance to $O$. novoulmi is limited but encouraging. This species has frequently been used in European breeding programmes because of its greater DED resistance than $U$. minor. This study confirms the suitability of this practice. Resis- 
tance to $O$. novo-ulmi increased significantly as a function of increased amounts of $U$. pumila germplasm from the female parent suggesting that DED resistance may be transmitted mainly by the mother. In (U. minor $\times U$. pumila $) \times U$. minor combinations, with $U$. pumila contributing approximately $25 \%$ to the germplasm, response to DED was sufficient to recommend this backcross for breeding purposes. DED resistance heritability estimates and genetic gains reported here indicate a high degree of additive genetic control and show that selection for DED resistance and rapid tree growth is effective.

\section{Acknowledgments}

This work is dedicated to Hans Heybroek, Lorenzo Mittempergher, Alberto Fagnani, Fabio Ferrini and Alberto Santini, who kindly shared their knowledge of elm breeding with AS, JCLA and LG. We thank Margarita Burónł for superb technical assistance, Christine Cahalan (University of Wales, Bangor) for help with the statistical analysis, Esther Merlo for a critical review, and Jane McGrath for language editing. Pictures (a) and (b) from Fig. 2 were taken by S. Dominguez and E. Martínez. AS was funded by the Regional Government of Extremadura Department of Education and Technology (Junta de Extremadura - Consejería de Educación y Tecnología) and the European Social Fund during a visit to $C$. Cahalan in Bangor. The study was funded by the Spanish Directorate-General of Rural Development and Forestry Policy, Ministry of Agriculture, Food and Environmental Affairs (Dirección General de Desarrollo Rural y Política Forestal, Ministerio de Agricultura, Alimentación y Medio Ambiente).

\section{References}

Bloom JS, Ehrenreich IM, Loo W, Vo Lite TL, Kruglyak L (2013). Finding the sources of missing heritability in a yeast cross. Nature 494: 234 237. - doi: 10.1038/nature 11867

Brasier CM (2000). Intercontinental spread and continuing evolution of the Dutch elm disease pathogens. In "The Elms: Breeding, Conservation and Disease Management" (Dunn CP ed). Kluwer Academic Publishers, New York, NY, USA, pp. 61-72. - doi: 10.1007/978-1-46154507-1 4

Bridgewater F (1992). Mating designs. In: "Handbook of quantitative forest genetics" (Fins L, Friedman ST, Brotschol JV eds). Kluwer Academic Publisher, Dordrecht, The Netherlands, pp. 69-95. - doi: 10.1007/978-94-015-7987-2

Cogolludo-Agustín MA, Agúndez D, Gil L (2000). Identification of native and hybrid elms in Spain using isozyme gene markers. Heredity 85: 157-166. - doi: 10.1046/j.1365-2540.2000. 00740.x

Falconer DS, Mackay TFC (1996). Introduction to quantitative genetics. Longmann \& co, London,
UK, pp. 464.

Fehr WR (1987). Principles of cultivar development'theory and technique (vol. 1). Iowa State University Press, Ames, USA, pp. 539.

Ghelardini L, Santini A (2009). Avoidance by early flushing: a new perspective on Dutch elm disease research. iForest 2: 143-153. - doi: 10.3832/ifor0508-002

Hallauer AR, Miranda JB (1988). Quantitative genetics in maize breeding. Iowa State University Press, Ames, IA, USA, pp. 468.

Helander ML, Vuorinen P, Saikkonen K, Lappalainen J (1998). Evidence for resistance of mountain birch (Betula pubescens ssp. czerepanovii) to birch rust (Melampsoridium betulinum). Mycological Research 102: 63-66. - doi: $10.1017 /$ S0953756297004437

Heslop-Harrison J, Heslop-Harrison Y (1970). Evaluation of pollen viability by enzymatically induced fluorescence: intracellular hydrolysis of fluorescein diacetate. Stain Technology 45: 115120. - [online] URL: http://informahealthcare.com/doi/abs/10.3109/10520297009085351

Heybroek HM (1957). Elm breeding in the Netherlands. Silvae Genetica 6: 112-117.

Le Cocq TL, Quiring D, Verrez A, Park YS (2005). Genetically based resistance of black spruce (Picea mariana) to the yellowheaded spruce sawfly (Pikonema alaskensis). Forest Ecology and Management 215: 84-90. - doi: 10.1016/j.foreco.2005.05.006

Lefevre F, Pichot C, Pinon J. (1994). Intraspecific and interspecific inheritance of some components of the resistance to leaf rust (Melampsoralarici populina $\mathrm{Kleb}$ ) in poplars. Theoretical and Applied Genetics 88: 501-507. - doi: 10.1007/ BF00223668

Lester DT, Smalley EB (1972a). Response of backcross hybrids and three-species combinations of Ulmus pumila, Ulmus japonica, and $U$. rubra to inoculation with Ceratocystis ulmi. Phytopathology 62: 845-848. - doi: 10.1094/Phy to- $62-845$

Lester DT, Smalley EB (1972b). Response of U1mus pumila and Ulmus pumila $\times$ rubra hybrids to inoculation with Ceratocystis ulmi. Phytopathology 62: 848-852. - doi: 10.1094/Phyto62-848

Lester DT, Smalley EB (1972c). Variation in ornamental traits and disease resistance among crosses of Ulmus pumila, U. rubra, and putative natural hybrids. Silvae Genetica 21: 193-197. [online] URL: http://allgemeineforstundjagdzei tung.com/fileadmin/content/dokument/archiv/silvaegenetica/21 1972/21-5-193.pdf

López-Almansa JC, Pannell JR, Gil L (2003). Female sterility in Ulmus minor (Ulmaceae): a hypothesis invoking the cost of sex in a clonal plant. American Journal of Botany 90: 603-609. - doi: 10.3732/ajb.90.4.603

López-Almansa JC, Yeung EC, Gil L (2004). Abortive seed development in Ulmus minor (Ulmaceae). Botanical Journal of the Linnean Society 145: 455-467. - doi: 10.1111/j.1095-8339. 2004.00297.x

Martín JA, Solla A, Woodward S, Gil L (2005).
FT-IR spectroscopy as a new method for evaluating host resistance in the Dutch elm disease complex. Tree Physiology 25: 1331-1338. - doi: 10.1093/treephys/25.10.1331

Martín JA, Solla A, Domingues MR, Coimbra MA, Gil L (2008). Exogenous phenol increase resistance of Ulmus minor to Dutch elm disease through formation of suberin-like compounds on xylem tissues. Environmental and Experimental Botany 64: 97-104. - doi: 10.1016/j.envexpbot. 2008.05.004

Martín JA, Solla A, Esteban LG, de Palacios P, Gil L (2009). Bordered pit and ray morphology involvement in elm resistance to Ophiostoma novo-ulmi. Canadian Journal of Forest Research 39: 420-429. - doi: 10.1139/X08-183

Martín JA, Solla A, Witzell J, Gil L, GarcíaVallejo MC (2010). Antifungal effect and reduction of Ulmus minor symptoms to Ophiostoma novo-ulmi by carvacrol and salicylic acid. European Journal of Plant Pathology 127: 21-32. doi: 10.1007/s10658-009-9567-3

Martín JA, Solla A, García-Vallejo MC, Gil L (2012). Chemical changes in Ulmus minor xylem tissue after salicylic acid or carvacrol treatments are associated with enhanced resistance to Ophiostoma novo-ulmi. Phytochemistry 83: 104 109. - doi: 10.1016/j.phytochem.2012.07.017

Martín JA, Solla A, Ruiz-Villar M, Gil L (2013). Vessel length and conductivity of Ulmus branches: ontogenetic changes and relation to resistance to Dutch elm disease. Trees 27: 12391248. - doi: 10.1007/s00468-013-0872-2

Martín JA, Solla A, Venturas M, Collada C, Domínguez J, Miranda E, Fuentes P, Burón M, Iglesias S, Gil L (2014). Seven Ulmus minor clones tolerant to Ophiostoma novo-ulmi registered as forest reproductive material in Spain. iForest (early view): e1-e9. - doi: 10.3832/ifor 1224-008

Mittempergher L, La Porta N (1991). Hybridization studies in the Eurasian species of elm ( $\mathrm{Ul}$ mus spp.). Silvae Genetica 40: 237-243.

Mittempergher L, Santini A (2004). The history of elm breeding. Investigación Agraria: Sistemas y Recursos Forestales 13: 161-177. [online] URL: http://www.inia.es/gcontrec/pub/161-177-(14)the_history_1161943529015.pdf

Nyquist WE (1991). Estimation of heritability and prediction of selection response in plant populations. Critical Reviews in Plant Sciences 10: 235-322. - doi: 10.1080/07352689109382313 Pinon J, Husson C, Collin E (2005). Susceptibility of native French elm clones to Ophiostoma novo-ulmi. Annals of Forest Science 62: 689696. - doi: 10.1051/forest:2005066

Pope SA (1943). Some studies on the Dutch Elm Disease and the causal organism. Doctoral thesis, Cornell University, Ithaca, NY, USA, pp. 61. Richens RH (1983). Elm. Cambridge University Press, Cambridge, UK, pp. 347. [online] URL: http://www.cabdirect.org/abstracts/19840690795 .html

Santini A, Ghelardini L, Falusi M, Bohnens J, Buron M, Collin E, Solla A, Vanden Broeck A (2004). Vegetative budburst variability of Euro- 
pean elms. Investigación Agraria: Sistemas y Recursos Forestales 13: 37-45. [online] URL: http://revistas.inia.es/index.php/fs/article/viewAr ticle $/ 811$

Santini A, Fagnani A, Ferrini F, Ghelardini L, Mittempergher L (2005). Variation among Italian and French elm clones in their response to Ophiostoma novo-ulmi inoculation. Forest $\mathrm{Pa}$ thology 35: 183-193. - doi: 10.1111/j.1439-03 29.2005.00401.x

Solla A, Gil L (2002). Influence of water stress on Dutch elm disease symptoms in Ulmus minor Miller. Canadian Journal of Botany 80: 810-817. - doi: 10.1139/b02-067

Solla A, Gil L (2003). Evaluating Verticillium dahliae for biological control of Ophiostoma novo-ulmi in Ulmus minor. Plant Pathology 52: 579-585. - doi: 10.1046/j.1365-3059.2003.0092 1.x

Solla A, Bohnens J, Collin E, Diamandis S, Franke A, Gil L, Burón M, Santini A, Mittempergher L, Pinon J, Vanden Broek A (2005a). Screening European elms for resistance to Ophiostoma novo-ulmi. Forest Science 51: 134141. [online] URL: http://www.ingentaconnect.com/content/saf/fs/2005/00000051/00000002/art 00005

Solla A, Martín JA, Ouellette G, Gil L (2005b). Influence of plant age on symptom development in Ulmus minor following inoculation by Ophiostoma novo-ulmi. Plant Disease 89: 10351040. - doi: 10.1094/PD-89-1035

Solla A, Dacasa MC, Nasmith C, Hubbes M, Gil L (2008). Analysis of Spanish populations of Ophiostoma ulmi and O. novo-ulmi using phenotypic characteristics and RAPD markers. Plant Pathology 57: 33-44. - doi: 10.1111/j.13653059.2007.01692.x

Strong DR, Larsson S, Gullberg U (1993). Heritability of host plant resistance to herbivory changes with gall midge density during an outbreak on willow. Evolution 47: 291-300. - doi: $10.2307 / 2410136$

Tchernoff V (1965). Methods for screening and for the rapid selection of elms for resistance to Dutch elm disease. Acta Botanica Neerlandica 14: 409-452. - doi: 10.1111/j.1438-8677.1965. tb00204.x

Venturas M, López R, Martín JA, Gascó A, Gil L (2014). Heritability of Ulmus minor resistance to Dutch elm disease and its relationship to vessel size, but not to xylem vulnerability to drought. Plant Pathology 63: 500-509. - doi: 10.1111/ppa. 12115

Vivas M, Martín JA, Gil L, Solla A (2012a). Evaluating methyl jasmonate for induction of resistance to Fusarium oxysporum, F. circinatum and Ophiostoma novo-ulmi. Forest Systems 21: 289-
299. - doi: 10.5424/fs/2012212-02172

Vivas M, Zas R, Solla A (2012b). Screening of Maritime pine (Pinus pinaster) for resistance to Fusarium circinatum, the causal agent of Pitch Canker disease. Forestry 25: 185-192. - doi: 10.1093/forestry/cpr055

White TL, Adams WT, Neale DB (2007). Forest genetics. CABI Publications, Cambridge, MA, USA, pp. 682. [online] URL: http://books. google.com/books?hl=en\&id=_MKWuexx52YC Zas R, Solla A, Sampedro L (2007). Variography and kriging allow screening Pinus pinaster resistant to Armillaria ostoyae in field conditions. Forestry 80 (2): 201-209. - doi: 10.1093/forestry/ cp1050

Zürcher ER (1986). Sprossachsen-Ontogenie der Bergulme (Ulmus glabra Huds.), bei Normalund Langtagbedingungen [Stem ontogeny of Wych elm (Ulmus glabra Huds.) under normal and long day conditions]. Vierteljahrsschrift der Naturforschenden Gesellschaft in Zürich 131: 235-294.

\section{Supplementary Material}

Appendix 1 - Plant material specifications.

Link: Solla_1227@supp1001.pdf 